Western University

Scholarship@Western

2015

\title{
Constructing 'Farmer' and 'State' Identities in Moral Discourses about Semi-subsistence Agriculture in North-east Brazil
}

Karen E. Pennesi

University of Western Ontario, pennesi@uwo.ca

Follow this and additional works at: https://ir.lib.uwo.ca/anthropub

Part of the Agriculture Commons, Latin American Languages and Societies Commons, Latin American Studies Commons, Linguistic Anthropology Commons, Place and Environment Commons, Rural Sociology Commons, Social and Cultural Anthropology Commons, and the Work, Economy and Organizations Commons

Citation of this paper:

KAREN PENNESI (2015). Constructing 'Farmer' and 'State' Identities in Moral Discourses about Semi-subsistence Agriculture in North-east Brazil. Journal of Latin American Studies, 47, pp 781-809 doi:10.1017/S0022216X1500084X 
This is the accepted manuscript published in the Journal of Latin American Studies.

\section{Citation:}

KAREN PENNESI (2015). Constructing 'Farmer' and 'State' Identities in Moral Discourses about Semi-subsistence Agriculture in North-east Brazil. Journal of Latin American Studies, 47, pp 781-809

doi:10.1017/S0022216X1500084X 
Constructing 'Farmer' and 'State' Identities in Moral Discourses about Semisubsistence Agriculture in Northeast Brazil 


\begin{abstract}
Anthropological analysis elucidates how discourses about agriculture in one Northeast Brazilian community reflect relational roles of citizens and the state, the position of farmers in society, and the relationship of individuals to their work. In these discourses, farmers are positioned as moral, hard-working, autonomous citizens, justifying their participation in low-paying activities. The decreased number of agricultural workers is explained as resulting from individual laziness or government's irresponsibility. In using these discourses to take stances publicly on agricultural issues, speakers assign responsibilities and moral status to agents. In constructing rural identities, such moral discourses emphasise the symbolic value of subsistence agriculture as its economic value declines.
\end{abstract}

Keywords: semi-subsistence agriculture; moral discourse; discourse; identity construction; Northeast Brazil 


\section{Moral discourses and agricultura}

Applying theories and techniques from linguistic anthropology, I elucidate how discourses about agriculture reflect and shape understandings of the roles of citizens and the state, the position of farmers in society, and how individuals relate to their work. Specifically, I analyse how semi-subsistence farmers talk about farming and agricultural workers as they express their understanding of, and their role within, processes of market liberalisation. I present a close look at Quixadá in the interior of Ceará, Northeast Brazil, where discourses about the moral value of farm work contrast with talk about the increasing number of potential workers who are not engaging in agricultural activities. A positive stance toward agriculture is used to justify participation in semi-subsistence farming in the pursuit of autonomy and moral standing as well as involvement in political struggles to improve conditions. At the same time, lack of participation in farming is explained by two competing discourses suggesting either that those who do not farm are lazy or that government is failing to meet its responsibilities. My analysis of these discourses advances the idea that in taking a particular stance on agricultural issues in public contexts, speakers construct moral identities which assign responsibilities to specific agents and include expectations about how these agents should act. References to these moral responsibilities are then used in persuasive discourse which emphasises the symbolic value of subsistence 
agriculture in the construction of rural identities, as its economic value declines.

Recent literature on the effects that neoliberal economic policies toward agriculture are having on the peasantry, and their strategies for coping with these changes in the context of globalised agriculture, tends to take one of two approaches. Some scholars illuminate the engagement of peasants with large scale processes such as international trade relations, national policies and agribusiness practices. ${ }^{1}$ These studies, which emphasise how farmers relate to the state or to markets through commoditisation, are important for providing economic, historical, social and political context which enriches analyses of choices (and their constraints) made by farmers. The approach taken here contributes to complementary micro-level perspectives on how subsistence and semisubsistence farmers express their understanding of, and their place within, these larger processes as they take shape. For example, Fitting examines local narratives about corn agriculture in Mexico to understand generational differences in attitudes toward agricultural livelihoods. ${ }^{2}$ In Finland, Niska and colleagues report on farmers' values and how they frame the guiding principles of their farm

\footnotetext{
${ }^{1}$ Sergio Schneider and Paulo André Niederle, 'Resistance Strategies and Diversification of Rural Livelihoods: The Construction of Autonomy among Brazilian Family Farmers', Journal of Peasant Studies, 37: 2 (2010), pp. 379-405; Jan Douwe van der Ploeg, 'The Peasantries of the twenty-first century: the commoditisation debated revisited', Journal of Peasant Studies, Vol. 37, No. 1 (2010), pp. 1-30.

${ }^{2}$ Elizabeth Fitting, The Struggle for Maize: Campesinos, Workers, and Transgenic Corn in the Mexican Countryside (Durham: Duke University Press, 2011).
} 
business, describing the relative importance farmers place on autonomy, profit and the wellbeing of nature. ${ }^{3}$ The authors treat 'peasantry' and 'entrepreneurship' as socially constructed frames for guiding understanding of what farming is about, allowing them to investigate differences and disagreements about interpretations of farming. In keeping with interpretive analysis I attend to identity formation processes to understand relational roles in a rural community within the changing socioeconomic and political context.

Grounded in an ethnographic understanding of rural Ceará, I explore moral discourses involving how farmers relate to each other, to other members of their local communities, to the state, and to the work itself. Departing from other research on pejorative discourses about peasants, in which non-farmers and other institutional or governmental entities promote particular visions of subsistence agriculture, ${ }^{4}$ I ask how Quixadá farmers use agricultura (ideas about farming and agricultural labourers) symbolically to talk about their peers and their own relationship to the state. Investigation reveals contradictory discourses are employed as farmers 'reconcile their personal circumstances with a view of how

\footnotetext{
${ }^{3}$ Miira Niska, Hannu Vesala and Kari Mikko Vesala, 'Peasantry and Entrepreneurship as Frames for Farming: Reflections on Farmers' Values and Agricultural Policy Discourses', Sociologia Ruralis, 52: 4 (2012), pp. 453-66.

${ }^{4}$ Diana Mincyte, 'Subsistence and Sustainability in Post-Industrial Europe: The Politics of Smallscale Farming in Europeanising Lithuania', Sociologia Ruralis, Vol. 51, No. 2 (2011), pp. 101-18; Susan Carol Rogers, 'Good to Think: The "Peasant" in Contemporary France', Anthropological Quarterly, 60: 2 (1987), pp. 56-63.
} 
the world ought to work'. 5 They construct moral stances toward neoliberal policies and perspectives in relation to agricultura which are enacted in daily interactions. Through such quotidian experiences, larger historical or political processes take shape; therefore, an ethnographic approach which includes discourse analysis makes visible the emergence of identity categories in relation to each other and the social construction of knowledge. ${ }^{6}$

I use the Portuguese term agricultura to preserve the cultural context and connotations associated with the word in Quixadá. Roughly translated as 'agriculture', discourse surrounding agricultura includes talk about subsistence or semi-subsistence farming activities as well as paid agricultural labour (sometimes simply called 'work' or trabalho) and the more abstract concept of agriculture as a mode of production (i.e. peasant farming, not entrepreneurial or capitalist agriculture). ${ }^{7}$ In my data discourses about agricultura refer to 'farmers', specified as agricultores, produtores, or trabalhadores rurais, all of whom are understood to be poor, with little (less than 10 hectares) or no land ownership and relying on local markets to sell their produce directly to townspeople or occasionally to

\footnotetext{
${ }^{5}$ Wendy Wolford, 'The Difference Ethnography Can Make: Understanding Mobilization and Development in the Brazilian Northeast', Qualitative Sociology, 39: 3 (2006), p. 349. ${ }^{6}$ Ibid, p. 350.

${ }^{7}$ For comparative examples, see Ana Carolina Bordini Brabo Caridá, 'Agricultura Camponesa X Agronegócio: distintos modelos de desenvolvimento rural e seus diferentes projetos socioeducacionais', Revista IDeAS: Interfaces em Desenvolvimento, Agricultura e Sociedade, 6: 1 (2012), pp. 33-49; van der Ploeg, 'The Peasantries of the twenty-first century'.
} 
traders. I use 'farmer' in this way. Finally, agricultura evokes ideas often associated with peasantry: connections between farmers and the land, continuity and 'tradition', physical labour performed by family members, a subsistence ethic, and identities based in rural or agrarian life. ${ }^{8}$

With rural households increasingly relying on non-farm sources of income, ${ }^{9}$ not only in Northeast Brazil but in regions throughout Latin America and Africa, ${ }^{10}$ the economic importance of subsistence farming is diminishing. Meanwhile, subsistence farming as a way of life continues to hold symbolic value for many of those who are involved in it, despite the social, political and economic disadvantages that these farmers face. ${ }^{11}$ One Quixadá farmer describes the non-economic values agricultura holds:

When the rain falls, if I don't plant, I get sick. I'm going to get stressed, I'm going to have a thousand problems with my health because I don't plant...Planting is good for health. It's a beautiful thing when you arrive in the field to have corn,

8 James Scott, The Moral Economy of the Peasant: Rebellion and Subsistence in Southeast Asia (New Haven: Yale University Press, 1976); Teodor Shanin (ed.), Peasants and Peasant Society (Oxford: Basil Blackwell, 1987).

${ }^{9}$ Francisco Ferreira and Peter Lanjouw, 'Rural Nonfarm Activities and Poverty in the Brazilian Northeast', World Development, 29: 3 (2001), pp. 509-28.

10 Thomas Reardon, Julio Berdegué and Germán Escobar, 'Rural Nonfarm Employment and Incomes in Latin America: Overview and Policy Implications', World Development, 29: 3 (2001), pp. 395-409.

${ }^{11}$ Rudi Colloredo-Mansfeld, Fighting Like a Community: Andean Civil Society in an Era of Indian Uprisings (Chicago: University of Chicago Press, 2009). 
watermelon, squash, etc. and to have the fruit and everything. You get there and hack a watermelon open with the knife and you eat it. You get a sack of corn and bring it home. You arrive and eat pamonha [corn tamale], canjica [sweet white corn pudding] etc. You fill your face with chicken, with pork, with everything. What could be better?

Examining discourses about agricultura contributes to anthropological understandings of the impact of large-scale economic processes on rural households and communities who derive livelihoods primarily from agriculture, adding a moral and symbolic dimension to analyses of the political and socioeconomic contexts of farm work.

To explain how discourses of agricultura reflect and (re)create relational roles, I treat discourse as social action through which identities and relationships are formed. Stance-taking is a particular kind of discourse in which identity construction is salient. I have selected examples of stance-taking occurring within the performance of public discourse to illustrate how talk in such contexts is important in creating and reinforcing identities as well as in indicating expected actions. This conceptual framework is briefly outlined below.

Here, discourse refers to 'language use relative to social, political and cultural formations - it is language reflecting social order but also language 
shaping social order, and shaping individuals' interaction with society'. ${ }^{12}$

Discourse analysis examines the relationship between language, power and social identities. Research on talk-in-interaction has shown how language is used to construct, reproduce and transform social identities. ${ }^{13}$ Rather than essential aspects of an individual, identities are constituted in talk and social practice, so that identities are continuously being performed, negotiated and evaluated. Through repetition linguistic practices, like other social practices, shape our way of being and acting. ${ }^{14}$ By making particular linguistic choices in relation to everchanging contexts, we are continuously engaged in constructing our own identities as well as identifying others. An examination of discourse surrounding a particular topic (e.g. subsistence farming) can illuminate how certain agents are identified positively or negatively, as responsible or powerless, or as fulfilling a particular role. A foundational principle of linguistic anthropology is that consideration of the context of speech events is essential to understanding how language use is related to social order. The socioeconomic and political contexts

12 Adam Jaworski and Nikolas Coupland (eds.), The Discourse Reader (New York: Routledge, 1999), p. 3, emphasis added.

13 Laura Ahearn, Living Language: An Introduction to Linguistic Anthropology. (Oxford: Wiley Blackwell, 2012); Michael Bamberg, Anna De Fina and Deborah Schiffrin (eds.), Selves and Identities in Narrative and Discourse (Philadelphia: Wiley Blackwell, 2007); Jaworski and Coupland, The Discourse Reader (1999).

14 Pierre Bourdieu, Outline of a Theory of Practice (Cambridge: Cambridge University Press, 1977). 
in which talk about agricultura is embedded are, therefore, given special attention.

In the articulation of a particular discourse, community members evaluate others' talk as well as policies and practices related to agriculture. Evaluation is part of stance-taking, whereby speakers position themselves as one kind of moral agent while aligning themselves with or opposing themselves to other agents as they convey attitudes or opinions about something. ${ }^{15}$ Stance-taking is both a linguistic act and a social act. Taking into account the interactional contexts in which specific instances of stance-taking on agricultural issues occurs, I bring in relevant socio-political relationships, economic policies and moral beliefs to help elucidate the consequences and implications of these stances. As Du Bois and Englebretson observe, stance is consequential, having real impacts on the people involved. ${ }^{16}$ Thus, an examination of stance-taking in discourses about farming can make visible the development of relational roles through which certain agents are positioned as responsible for the decline, as well as the survival, of semisubsistence agriculture in Quixadá.

\section{Method}

The majority of the data come from field trips to Quixadá, in 2010 and 2011,

15 John Du Bois, 'The Stance Triangle', in Robert Englebretson (ed.), Stancetaking in Discourse: Subjectivity, Evaluation, Interaction (Philadelphia: John Benjamins, 2007), pp. 139-82.

16 Ibid, p. 141; Robert Englebretson (ed.), Stancetaking in Discourse: Subjectivity, Evaluation, Interaction (Philadelphia: John Benjamins, 2007), p. 6. 
supplemented by research done in rural Ceará over eight years (2003-2011). The main focus of that research was the generation, interpretation and use of climate forecasts by semi-subsistence and subsistence farmers. ${ }^{17}$ I recorded observations, interviews and interactions in which people discussed rain predictions, farming, social problems, economic hardships and government policies. Discourse about rain prediction often provided the context in which discourse about agriculture and society emerged. Participants ranged in age from early thirties to midnineties. The data include naturally occurring talk among people I did not subsequently interview so that I do not always have details about the speaker's background, such as level of education, age or non-farm sources of income. I do not claim that the discourses discussed here are representative of Quixadá's population in any statistical sense. For example, nearly all of these recorded interactions involved adult men since women were less likely to identify themselves as farmers in terms of occupation and they were reluctant to speak

\footnotetext{
${ }^{17}$ Karen Pennesi, 'Improving Forecast Communication: Linguistic and Cultural Considerations', Bulletin of the American Meteorological Society, 88: 7 (2007), pp. 1033-1044; 'Making Forecasts Meaningful: Explanations of Problematic Predictions in Northeast Brazil', Weather, Climate and Society, 3: 2 (2011), pp. 90-105; Karen Pennesi and Carla Renata de Souza, 'O encontro anual dos profetas da chuva em Quixadá, Ceará: A circulação de discursos na invenção de uma tradição', Horizontes Antropológicos, 38 (2012), pp. 159-186.
} 
with researchers about climate forecasting, deferring to the men of the household. In the public conversations I recorded, men were the dominant speakers. While there is some evidence in the data set that women talk in similar ways about agriculture, the gender bias means that potential alternative discourses may have been missed. Acknowledging these limitations, I report on structural and thematic patterns found in my data set and which I have observed to be salient during interactions with Quixadá residents.

I coded field notes and 82 transcripts (67 interviews and 15 public interactions) using Atlas.ti ${ }^{\odot}$, software for qualitative data analysis..$^{18}$ Themes include: the 'courage' required for agricultural work; buying, selling and prices; government policies and politics; rain predictions encouraging agricultural activities; and relations between social groups. I identified linguistic patterns and relations among common themes, paying particular attention to how stances were taken up and responded to.

The Portuguese transcripts are represented in two forms: short quotations and longer vignettes. Short quotations are direct translations from Portuguese and appear in quotation marks or indented blocks. Vignettes also include direct translations in quotation marks but these are embedded in descriptive prose paraphrasing other aspects of the interactions. The vignettes exemplify some of

18 Susanne Friese, Qualitative Data Analysis with Atlas.ti (Los Angeles: Sage, 2002). 
the different ways stance-taking on moral identity issues is incorporated into discourses about agricultura. 'Selling Beans' illustrates how negative stances toward agricultura are reproduced in spontaneous everyday encounters, such as commercial interactions. In 'Farmers Should Work' and 'Government Should Assist Farmers', traditional rain forecasters define certain moral identities as they promote agricultura in their on-stage public predictions. 'No one Wants to Work' and 'A Lack of Commitment' portray negative stances toward non-workers and government taken by other Quixadá residents, which provide counterpoints to explicitly positive public stances. Particular stances toward farmers, non-working citizens and the state are constructed in discourses about agricultura, according to the interactional context. Whether the talk is spontaneous or prepared, the stancetaker is identified as a moral agent who fulfils expectations and responsibilities in contrast to other agents who fail to do so.

\section{Agricultura in Quixadá, Ceará}

With poor soils and a drought-prone climate, conditions have never been ideal for rain fed farming in Ceará. Nonetheless, 80 per cent of Ceará's rural workforce is involved in agriculture, largely on small-scale family farms. ${ }^{19}$ Subsistence

19 Secretaria de Agricultura e Pecuária (SEAGRI), 'II plano indicativo de desenvolvimento rural do Ceará 1999-2002: Rumo ao desenvolvimento rural do Ceará', (Fortaleza: Governo do Ceará, 
farming is decreasingly viable, however, as neoliberal state policies under the administrations of Fernando Henrique Cardoso, Lula da Silva and Dilma Rousseff have deliberately favoured the development of agribusiness over 'family farming' in the last two decades. ${ }^{20}$ Ceará has one of the lowest per capita incomes in Northeast Brazil. ${ }^{21}$ Of Quixadá's 80,000 residents, 87 per cent had a per capita monthly income of Reais $\$ 510$ (US \$302) or less in 2010, with 38 per cent of rural residents classified as 'extremely poor' (per capita monthly income $\leq \mathrm{R} \$ 70$ or US \$41). ${ }^{22}$ The consensus among interviewees in Quixadá was that there is no economic incentive to engage in agricultural work. The cost of materials and labour has risen substantially in recent decades, while the prices the produce yields have stayed low. ${ }^{23}$ Ronaldo, a farmer in his sixties who raises goats and

2002).

${ }^{20}$ Anthony Pereira, 'Brazil's Agrarian Reform: Democratic Innovation or Oligarchic Exclusion Redux?', Latin American Politics and Society, 45: 2 (2003), pp. 41-65; James Petras and Henry Veltmeyer, 'Whither Lula's Brazil?: Neoliberalism and 'Third Way' Ideology', Journal of Peasant Studies, 31: 1 (2003), pp. 1-44; Wendy Wolford, 'Agrarian Moral Economies and Neoliberalism in Brazil: Competing Worldviews and the State in the Struggle for Land', Environment and Planning A, 37 (2005), pp.241-61.

${ }^{21}$ Food and Agriculture Organization (FAO), Rural Poverty in Brazil. Available at http://www.ruralpovertyportal.org/web/guest/country/ home/tags/brazil, 2011.

22 Instituto de Pesquisa e Estratégia Econômica do Ceará (IPECE), Perfil Básico Municipal 2011: Quixadá. Available at http://www.ipece.ce.gov.br/publicacoes/perfil_basico/pbm2011/Quixada.pdf, 2011.

${ }^{23}$ I was unable to obtain meaningful and consistent price data for corn, beans and rice produced in Ceará during the period 1994-2014 due to the change in currency and regional variation in commodity prices. I have therefore represented the farmers' experience of price changes with a quote containing specific costs for typical commodities. See Andre Averbug, 'The Brazilian Economy in 1994-1999: From the Real Plan to Inflation Targets', The World Economy, 25: 7 (2002), pp. 925-944, for an explanation of the currency change with the Real Plan in the context of international trade liberalisation and subsequent inflation. 
grows corn, beans, squash and other vegetables, explains the relationship between state policies oriented toward international or national markets and the economic difficulties of local small farmers which contribute to the lack of motivation.

It's a political problem. After the Real Plan, agriculture was finished... Today, to work in agriculture, there has been inflation since the Real Plan of '94 to now, of a thousand per cent and our produce never increased [in value]. Beans only go up when there is a good harvest. Corn, rice, vegetables, milk [do not increase] — milk is even cheaper than it was [before 1994], meat is even cheaper than it was. I have an example for you. I had some cash in my pocket and I went to Quixadá [centre]...to exchange at the bank, to receive the new bills [when the currency changed from the Cruzeiro Novo to the Real in 1994]. So I needed some wire. I bought ten rolls of wire at the co-op for $\mathrm{R} \$ 270$. Ten rolls of wire my money was enough to buy...He put on the receipt $R \$ 270$ for wire and $R \$ 7.50$ for 10 kilos of clamps. You know how much it is today? 10 rolls of wire is $\mathrm{R} \$ 2,000$ and the clamps are $\mathrm{R} \$ 80$. So then how can you work in agriculture? And you need the wire and you need the clamps. That's the way it is. The inflation of products went up so much you can't use them. The problem of the minimum wage. A day's work was $\mathrm{R} \$ 2$ 
that we paid [for seasonal labourers]. Today it's $\mathrm{R} \$ 20$. And the [price of] produce is way down there. Milk is low. A litre of milk is selling for 55 cents. How can you? You can't? So the problem of the discouraged youth is exactly this. If he's from a family of farmers, he soon goes to the periphery of the [big] cities...He goes where there is industry. And we who have a property and need their labour, and the price is so high. A scythe was $\mathrm{R} \$ 1$, today it's $\mathrm{R} \$ 30$, understand? A kilo of cable was $\mathrm{R} \$ 2$, today it's $\mathrm{R} \$ 15$. Diesel oil that farming requires was less than 20 cents, today it's $\mathrm{R} \$ 2$ and a bit. So how are there conditions to produce? When corn is the same price, beans are the same price, meat is the same price, milk is the same price. That's it. The government created a disastrous policy. The basic basket [of food staples] didn't rise for the consumer and we're paying for it...Last year with the price of corn that we produced and sold, it wasn't enough to harvest it and bring it home. I planted in a difficult area to access, with no road. I had to bring it in by donkey, understand. I spent more money bringing it home than to produce it. How am I going to grow [crops]? How am I going to survive? I'm not going to survive.

Another farmer asserts, 'I have lost a lot of money from liking agriculture.' he 
defends the children of farmers who refuse to do the same work because:

They see their father killing himself and he can't get

ahead...Don't believe that no one wants to work. Everyone wants

work. But what happens is that if there is no return, you are not

going to work for free for anyone.

The impacts on Brazilian peasant farmers of neoliberal economic and

political policies implemented since the 1980s are well-documented. ${ }^{24}$

Neoliberalism is characterised by privatization, marketization, deregulation or

market-friendly reregulation, the reduction of state subsidies and social supports, and the creation of 'self-sufficient' individuals and communities. ${ }^{25}$ In Brazil, this has meant less access to land for those too poor to buy it, reduced access to credit for those who do not own land, the continued reliance on variable rainfall due to inability to pay for irrigation infrastructure and water delivery, and drastic drops in small producer earnings due to the elimination of tariffs and government price regulation. ${ }^{26}$ In these conditions, semi-subsistence farmers in Ceará cannot

\footnotetext{
24 Anthony Pereira, 'Brazil's Agrarian Reform'; Petras and Veltmeyer, 'Whither Lula's Brazil?'; Schneider and Niederle, 'Resistance Strategies'

25 Noel Castree, 'Neoliberalism and the Biophysical Environment 1: What 'Neoliberalism' is, and What Difference Nature Makes to it', Geography Compass, 4: 12 (2010), pp. 1725-33.

${ }^{26}$ Food First, Institute for Food and Development Policy, 'Agricultural Trade Liberalization and Brazil's Rural Poor: Consolidating Inequality'. Available at http://www.foodfirst.org/en/node/267, 2003; Angela Steward, 'Nobody Farms Here Anymore: Livelihood Diversification in the Amazonian Community of Carvão, a Historical Perspective', Agriculture and Human Values, 24: 1 (2007), pp. 75-92.
} 
successfully compete with the lower prices and reliability of supply offered by larger, mechanised, government-subsidised operations. The following vignette illustrates how the problem is both an economic and a social one.

\section{Selling beans: 'This has no future'}

Dorval has owned a shop in downtown Quixadá for 40 years, selling bulk grains and household items. He buys 80 per cent of his grains from other Northeastern states because in Ceará, 'no one produces anything anymore,' even in a year with a good rainy season. 'If they had to eat what is produced here, they'd all die of hunger,' he repeats. Freight costs keep prices high, Dorval says, but it's still better to buy the higher quality grains from large-scale producers out of state, who provide a reliable supply by the truckload more cheaply than what local farmers want for their few surplus sacks. Dorval theorises that the Rural Workers' Union, the federal Worker's Party and the Catholic Church are responsible for the end of small scale agriculture as a viable livelihood in Ceará because they incited the workers to fight with the landowners who could not afford to pay them what they demanded. The landowners subsequently hired fewer workers or refused to rent out their land to sharecroppers, forcing the uneducated, unskilled farmers into town where there was also no work. Economic and moral decline has been the trend ever since, he concludes. A farmer then enters, carrying a sack of beans. He 
sets the sack down in front of Dorval's desk and opens it, scooping up some beans and letting them cascade back into the sack in a rhythmic display.

The farmer interrupts: 'Let me show you this merchandise here'.

'Hmm,' Dorval replies, uninterested. 'Where are they from, these beans?

From Ceará?'

'Yeah. They come from Morada Nova,' (a neighbouring município).

'Hmm,' Dorval repeats. 'How much for one?'

The farmer pauses before suggesting his price: 'At least 200 or 210

(Reais) because it's good, you see?'

'I can get it from Mato Grosso (another state) for 140. I don't want it, meu filho!' (literally, 'my son'), Dorval says dismissively.

'Yeah?' the farmer asks.

'Yeah,' Dorval confirms, 'I don't want it. Understand? I don't want it.'

'Yeah but this here is different, see?' the farmer persists, still scooping and letting beans fall into the sack.

'Yeah, yeah,' Dorval agrees sarcastically, 'when we cook it, it'll turn into rice, right?'

The farmer does not respond to the derisive joke but asks Dorval how much he would pay for one sack.

'I don't want it,' Dorval repeats, now for the fourth time. 'I bought some 
for 140 and you're asking 200 for this. Não tem futuro isso.' ('That doesn't make sense.' Literally, 'This has no future.')

The farmer persists in a hopeful but not confident tone, looking down as he scoops the beans: 'So then, you say something, sir.'

‘Hmm. Will you give it for R \$130?' Dorval asks, irritated. The farmer stops scooping and does not respond. Dorval asks again if he will sell the sack of beans for $\mathrm{R} \$ 130$. After another pause the farmer says quietly, 'No. I won't give it for that.'

'Right then. That's why I said I didn't want it,' Dorval concludes. 'Yeah, all right,' says the farmer softly, leaving with his sack of beans. Similar to Linda Seligmann's analysis of conversations market women in Cuzco have with their customers, we can see how this particular linguistic exchange is "shaped by an understanding by participants of the roles they are expected to play and the history of the roles they and perhaps others have played." ${ }^{27}$ Throughout the conversation it is clear that Dorval, in his role as potential buyer, has both the social and economic advantage. The farmer demands Dorval's attention and attempts a sale: 'Let me show you this merchandise here.' Dorval immediately adopts a dismissive stance. He seizes the dominant

\footnotetext{
${ }^{27}$ Linda Seligmann, Peruvian Street Lives: Culture, Power and Economy among Market Women of Cuzco (Chicago, 2004), pp. 122.
} 
conversational role by asking questions that oblige the farmer to respond, denying him opportunities for persuasive talk. Dorval's questions prompt expected answers leading to his eventual declaration that he does not want to buy the beans. When the farmer attempts to change Dorval's mind after he has said 'I don't want it' three times, Dorval responds with a sarcastic comment. This insult represents what Seligmann identifies as a linguistic shift, marking a turning point in the conversation toward a failed transaction. Dorval's tired posture, his disdainful tone and his conversational dominance all construct a stance in which he evaluates the beans negatively, positions himself powerfully as decision-maker about the sale and the conversation's length, and aligns himself in opposition to the farmer. Meanwhile, both men attempt to define and control the social distance by choosing particular terms of address: the farmer uses terms of respect such as $O$ senhor ('sir') and patrão ('boss'), whereas Dorval condescendingly calls the farmer mеи filho ('my son') and ultimately treats him as an ignorant nuisance. In this buyer-seller relationship, the buyer has an advantage because he is not obliged to buy the goods, while the seller desperately needs the cash. Rather than creating solidarity between buyer and seller in a mutually beneficial exchange relationship, both the farmer's and Dorval's talk reproduce an unequal relationship both socially and economically.

Dorval rationalises his lack of support for local agricultura and his 
negative stance toward this particular farmer and his beans by appealing to shared understandings of the need to make a profit. Even as he observes the decline of agricultural livelihoods by stating 'no one produces anything here anymore,' and the negative effects of this on social and moral structures, Dorval does not acknowledge his participation in this situation by refusing to buy available local produce. Instead, having internalised a neoliberal individualist discourse, he holds the farmers responsible for their own difficulties, influenced by the church and political organizers. Dorval's stance on agricultura in Ceará, that there is no future for semi-subsistence producers who ask too high a price, is evident both in what he says explicitly and in the way he acts. In his embodiment of the discourse he contributes to the production of that reality. Thus, examining stance helps elucidate how the devaluing of semi-subsistence agriculture in Ceará is perpetuated both symbolically and economically. Repeated participation in such unconsciously negative and spontaneous interactions prompts the more explicit stance-taking in the kinds of public discourses to be analysed next.

The economic response of farmers to the reduction in agricultural income is to turn to government and nonfarm sources of income, including working as day labourers and selling handicrafts. Silva and Del Grossi describe the 'urbanization of rural areas' in Brazil that occurred as nonfarm employment 
increased in rural households during the 1980s and 1990s. ${ }^{28}$ They note that while nonfarm jobs such as domestic service and petty commerce generate more income than agricultural work, they are still among the lowest paying. As in other areas of Brazil and throughout Latin America, residents in Quixadá are unable to make a living solely from subsistence agriculture or from off-farm work. Households therefore combine both revenue sources, often with different members engaging in one kind of work or the other. Thus, there has been a shift from subsistence to semi-subsistence farming and then to a reduction in the proportion of household income farming represents as nonfarm sources become more important. Nonetheless, farmers remain poor.

This leads some people in Quixadá to take a negative stance toward unprofitable and undesirable agricultural work. Like the peasant maize producers in Mexico’s Tehuacán Valley described by Elizabeth Fitting, the decline of smallscale agriculture affects attitudes and choices of Quixadá youth. They prefer migration to urban areas in the region for wage work, or even longer distance migration, because as their Mexican counterparts observe, 'there is no money to be made in the cornfield'. ${ }^{29}$ They associate agriculture with older generations,

28 Jose Graziano Silva and Mauro Eduardo Del Grossi, 'Rural Nonfarm Employment and Incomes in Brazil: Patterns and Evolution', World Development, 29: 3 (2001), pp. 443-53.

29 Fitting, The Struggle for Maize, p. 12. 
which means 'tradition, poverty and burdensome work in the fields'.${ }^{30}$ Once young people leave they refuse to return to the farms because 'the work is difficult and the financial return is small and irregular'. ${ }^{31}$ Those who persevere tend to promote the moral and cultural values associated with agricultural production.

\section{Farmers, workers, citizens and the state}

Identities are constructed and negotiated through talk. ${ }^{32}$ Moral identities include expectations about what are considered acceptable or good actions and attitudes. This is especially apparent in what the sociologist Harvey Sacks called 'standardised relational pairs' (SRPs). ${ }^{33}$ The two categories that comprise the relational pair have 'standardised' rights and obligations in relation to each other so that 'by knowing actions, we infer the categories of the agents; by knowing categories of agents, we infer what they do'. ${ }^{34}$ The focus of this analysis is the citizen/state SRP constructed through agricultura discourses. The 'citizen'

\footnotetext{
30 Ibid, p. 197.

31 Ibid, p. 209.

32 Mary Bucholtz and Kira Hall, 'Language and Identity', in Alessandro Duranti (ed.), Companion to Linguistic Anthropology, (Malden, MA: Blackwell, 2004), pp. 369-94.

33 Harvey Sacks, 'On the Analyzability of Stories by Children', in John Gumperz and Dell Hymes (eds.), Directions in Sociolinguistics: The Ethnography of Communication, (New York: Holt, Rinehart and Winston, 1972), pp. 325-45.

34 Anssi Peräkylä and Johnanna Ruusuvuori, 'Analyzing Talk and Text', in Norman Denzin and Yvonna Lincoln (eds.), The Sage Handbook of Qualitative Research, (Thousand Oaks, CA: Sage, 2011), p.533.
} 
category contains subcategories which I call 'worker' and 'dependent'. For instance, farmers, as working citizens, have certain rights and obligations in relation to the state and vice versa. Citizens who are dependents rather than workers have a different relationship with the state. The categories and relationships of SRPs, along with the associated expectations they invoke, are culturally defined and therefore multiple. There is no universal agreement on which categories are complementary parts of a pair, what the responsibilities of category members are, or how particular actions or events should be evaluated. Here, I investigate how the standardised relational pair citizen/state emerges and is invoked in Quixadá. Public interactions, such as interviews or public meetings, are sites for identity construction where speakers create and display particular 'moral versions' of their own and others' identities, ${ }^{35}$ including those that form the citizen/state SRP.

The discourses analysed all have a moral component in that they contain positive or negative evaluations of agents, such as farmers and government, according to expectations for these categories as part of the relational pairs to which they are assumed to belong. These discourses emerge in interaction as

\footnotetext{
35 The concept of moral versions in narratives is introduced in Eleni Petraki, Carolyn Baker and Michael Emmison, "Moral Versions' of Motherhood and Daughterhood in Greek-Australian Family Narratives', in Michael Bamberg, Anna De Fina and Deborah Schiffrin (eds.), Selves and Identities in Narrative and Discourse, (Philadelphia: John Benjamins, 2007), pp. 107-32.
} 
people take stances on issues related to agricultura. In expressing opinions about what farmers, government and members of other identified categories should or should not do, or in describing the actions or inaction of these agents, speakers position themselves in alignment with or opposition to these categories. With frequent repetition in multiple interactions these stances become stabilised and are available as linguistic resources to draw on when explaining or validating a particular choice, action or state of affairs. In these discourses moral identity is constituted in part by moral actions. In Quixadá, work and farming in particular, is considered moral action. In contrast, being idle, dependent or engaging in fruitless or criminal activities is considered immoral. The moral value of subsistence farming is complicated, however, by the economic disadvantages faced by small-scale rain fed farmers in Quixadá. This results in the coexistence of competing discourses about the moral and economic values of agricultural work.

\section{Positive stances toward agricultura}

The constant fear of drought and the dire necessity to produce a sufficient harvest create a context in which seasonal climate information is cautiously sought out and then critically evaluated. Responding to this need in communities throughout 
Ceará, traditional rain forecasters known as 'rain prophets' (profetas da chuva)

make predictions which advise subsistence farmers about the rainy season. Many

rain prophets are older farmers who become known as rain prophets for their

talents in predicting whether the rainy season will be good for agriculture based

on their observations of changes in the ecosystem, the appearance of objects in the

night sky, and rituals. ${ }^{36}$ Rain prophets are consulted in everyday conversations

and at the start of each rainy season there is an organised Meeting of the Rain

Prophets during which about 35 of them volunteer to announce their predictions

publicly. In their predictions, most rain prophets I have recorded in Quixadá

encourage farmers to plant and promote agricultura. ${ }^{37}$ Previous research has

shown that optimistic predictions are appreciated and preferred by farmers

because they become motivated to work. ${ }^{38}$ The following vignettes illustrate how

some rain prophets use the Meeting of the Rain Prophets as an opportunity to

${ }^{36}$ Karen Pennesi, 'The Predicament of Prediction: Rain Prophets and Meteorologists in Northeast Brazil'. Unpubl. PhD diss., University of Arizona, 2007; Karla Patrícia Holanda Martins (ed.), Profetas da chuva (Fortaleza: Tempo d'Imagem, 2006), p. 226; Renzo Taddei, 'Of Clouds and Streams, Prophets and Profits: The Political Semiotics of Climate and Water in the Brazilian Northeast'. Unpubl. PhD diss., Columbia University, 2005.

37 Rain prophets have gained the attention of scholars and the media as representatives of traditional Northeastern culture, which is grounded in an agrarian identity. See Martins (ed.), Profetas da chuva (2006); Abelardo Montenegro, Ceará e o profeta de chuva (Fortaleza: Edições UFC, 2008). The role of rain prophets has become increasingly folklorised. See Pennesi and de Souza, 'O encontro anual'; Renzo Taddei, 'Oráculos da chuva em tempos modernos: Mídia, desenvolvimento econômico e as transformações na identidade social dos profetas do sertão', in Martins (ed.), Profetas da chuva, pp. 161-70. This can be understood in part as a response to the decreasing utility of predictions as technical guides to agricultural production.

${ }^{38}$ Pennesi, 'Improving Forecast Communication'; Pennesi, 'Making Forecasts Meaningful'. 
reinforce publicly the moral values associated with agricultural work by making a symbolic connection between a moral identity and a farmer identity. This includes explicit and implicit statements about the rights and obligations of farmers-asworker-citizens and government agents within the citizen/state SRP.

\section{Farmers should work}

At the 2011 Meeting of the Rain Prophets, they are taking turns announcing their seasonal rain predictions to a constantly changing audience assembled under the shade of mango trees besides the iconic Cedro dam. Spectators include local residents, students, tourists, researchers, and various reporters. Local authorities sit facing the audience. Many rain prophets address their remarks to farmers, largely absent, but who may hear them later through television or radio broadcasts.

Pedro, a well-known rain prophet and an active farmer, begins. ${ }^{39}$ 'Folks, the rainy season this year, well, for many it's already started.' Pedro explains that before, people had been feeding their animals because there was insufficient forage and many cattle died. 'But today,' Pedro says proudly, 'all the animals are stuffing their guts, they're getting full.' He continues with his optimistic message,

${ }^{39}$ All names have been changed. 
that the rains will begin between the $16^{\text {th }}$ and the $20^{\text {th }}$ of January and there will be plenty of rain after that. 'February is going to be the best month,' he predicts, adding that he has not seen such a good February since 1974.

That's why I say, people of Quixadá, they should plant, pull out weeds, don't go along with this laziness of waiting for the crop insurance, because it's a pittance. Now, let's plant, we'll have popcorn, mugunzá (corn and chicken stew), that's corn, we can make everything, right? That's why I tell you to plant between the $16^{\text {th }}$ and the $20^{\text {th }}$ of January. There's going to be a lot of rain and it will rain before that.

\section{Government should assist farmers}

At the 2010 Meeting of the Rain Prophets, Roberto from Itatira faces the head table, addressing the local authorities in a sombre voice, rather than addressing the audience. He predicts that 2010 'will be a year of more abundance than 2009' with six months of rain. Roberto then responds to the prediction given just before by Evaldo, the prefeito (head of local government) of Itatira and also a rain prophet. Evaldo had recommended that farmers wait until the end of February to plant because there would not be enough rain until then to moisten the soil sufficiently. He had also warned the local representative of the Secretary of 
Agricultural Development, Alfonso, not to distribute the seeds too soon. ${ }^{40}$ Roberto has a contrasting opinion:

My dear prefeito, Evaldo, the rainy season has probably already begun. Let's hope that our Alfonso will take the message to Dr. Camilo (secretary of Agricultural Development for Ceará) and soon in a short space of time the farmer will have the distribution of his seeds precisely so we can plant our fields in our rural areas. My dear Alfonso, take this message to our most excellent Mr. Carlos Souza, that probably, according to our experiences, 2010 will have six consecutive months of rain and will be a year of more abundance on the tables of the men and women of the countryside. That's our message as farmers and rural workers.

\section{Identifying moral agents by their actions}

These two speeches illustrate how some rain prophets construct moral versions of a farmer identity as they incorporate into their predictions descriptions of actions which are necessary for agricultural production. Both Pedro and Roberto make explicit the link between the expected future rainfall and the expected behaviour

\footnotetext{
${ }^{40}$ The state government distributes free drought-resistant seeds to small producers each year. The timing of the distribution is linked to expectations of sufficient rainfall to ensure the seedlings survive; however, farmers often complain that seeds are distributed too late.
} 
of farmers. After forecasting that February will be the best month, Pedro introduces the exhortation to follow with 'that's why I say', suggesting that it is the optimistic prediction that warrants his advice. He then addresses Quixadá farmers, saying 'they should plant, pull out weeds' and most precisely, 'plant between the $16^{\text {th }}$ and the $20^{\text {th }}$ of January.' More indirectly, Roberto expresses his expectation that farmers should plant by appealing to the government officers to distribute the seeds: 'soon in a short space of time the farmer will have the distribution of his seeds precisely so we can plant our fields'. The expectation Pedro and Roberto express is that when the rain begins, farmers should start planting. Pedro emphasises what farmers are expected to do: feed animals when there is no forage, plant, pull out weeds, and make popular corn-based foods. By including themselves in the activities associated with 'good farmer behaviour', both Pedro ('let's plant') and Roberto ('so we can plant') construct themselves as moral agents and as farmers.

Roberto's speech produces a moral version of the relationship between citizens and the state, in which citizens work and government provides assistance. In the context of the Meeting he expresses this as a prediction which is favourable for agriculture. The accuracy or certainty of Roberto's prediction is less important than the message he is sending, which is that it is time for government officers to distribute seeds. His prediction is both vague and exaggerated: 'more abundance 
than 2009', 'probably... six consecutive months of rain', 'a year of more abundance on the tables'. In contrast, the message and its path from one government officer to the next are expressed in detail: 'Let's hope that our Alfonso will take the message to Dr. Carlos and soon... the farmer will have the distribution of his seeds... Alfonso, take this message to... Mr. Carlos Souza... That's our message as farmers and rural workers.' Both Roberto and Pedro describe favourable rainfall conditions for agriculture in order to motivate people (farmers and government officers) to act in moral ways according to the expectations of the SRP farmer-as-worker-citizen/state.

The assumption underlying Pedro's and Roberto's speeches is that as moral citizens, farmers should work. This expectation is expressed when Pedro takes up a stance promoting work and a positive attitude in opposition to the morally weak position of dependence and laziness. He explicitly warns farmers: 'Don't go along with this laziness of waiting for the crop insurance because it's a pittance.' Taking a stance against laziness acknowledges that not everyone does work hard. Ostensibly, optimistic predictions of abundant rainfall are meant to encourage potentially 'lazy' farmers to plant and tend their fields by assuring them that a good outcome will reward their efforts. This moral discourse is also 
intertwined with a discourse of risk familiar to subsistence farmers, ${ }^{41}$ which suggests that the potential moral and economic gains are higher if they cultivate their fields than if they do nothing and accept the 'pittance' from the state-funded crop insurance. Thus, the moral version of 'farmer' constructed by these rain prophets includes notions of autonomy through work, while the state is indirectly negatively evaluated for failing to provide adequate support through insurance.

Decision-making is a complex process and nearly every decision will be influenced by a variety of factors. Therefore, it is impossible to make claims attributing a farmer's or politician's choices to the motivational speech of a particular rain prophet. Even farmers who say they appreciate the inspiration of rain prophets must also consider other sources of predictions as well as the resources they have available when deciding when, where and what to plant. The goal of analysing public stance-taking is not, therefore, to arrive at causal explanations for behaviour which can be verified but rather to better understand how identity categories take on meaning in relation to other constructed roles, including how people propagate their views by positioning themselves as having potential influence over others.

${ }^{41}$ Scott, The Moral Economy of the Peasant 
Negative stances: laziness and a lack of commitment

The discourse of laziness is elaborated in other contexts, typically by older people. They complain about the difficulty in finding agricultural labourers and the apparent lack of ambition among unemployed youth, who are criticised for spending their time drinking, doing drugs, committing crimes or sitting around. Ninguem quer trabalhar ('no one wants to work') is the common refrain. The following vignette illustrates how this discourse emerges in conversation and is used in the construction of stances which negatively evaluate those who do not work, emphasising the stance-takers' own moral worth as hard workers.

\section{'No one wants to work'}

Marcos, in his sixties, chats with Jeremias, almost eighty and still cultivating corn, beans and vegetables. Marcos recounts how two young men he hired to turn the soil in his father's fields using an animal-driven plough stopped for long breaks every hour and still wanted an above average wage. Marcos concludes: 'They don't want to work.... They don't want to do anything.' He blames 'the system' which allows people to get by without working, by relying on government assistance and pensions of family members. They get used to managing on these small amounts and never develop ambition to work for anything more, he 
explains. 'If I have someone who gives me everything, why am I going to do it? I'm going to put up my hammock and lie down.'

Jeremias agrees, contrasting the attitudes of youth today with those in the past. At seven years old, he had begun working in the fields with his father. 'In those times, everything was difficult, there was no government giving us work or anything.' People would work to buy or build a house, have a family, support themselves and work to improve their conditions gradually. 'Now,' he says, 'they don't work, they don't study, they get a girl pregnant after three or four months of dating and then throw her back to her father's house while they stay with their own family, everyone living off the parents and no one doing anything to get ahead or establish their own homes.'

When I asked why Jeremias continues working when he could be relaxing in a hammock with his government pension, he replied:

Work, it's a point of honour. To not be yelled at by anyone, or to do something without having been told to, to act on your own conviction, according to your own nature or spirit.... I'm used to it. But whoever doesn't have the coragem (courage) to work, really won't work, no matter how much you insist. Today they don't want to work. We see them in the streets, playing (cards or snooker) and drinking. None of them employed. 
I heard similar comments repeatedly in Quixadá. Travelling along rural roads, people would call my attention to areas where people could have planted small crops but did not because 'they don't want to work'. Passing groups of young people sitting on a porch or playing snooker in outdoor bars, they were pointed out as evidence of laziness and lack of productivity. ${ }^{42}$

\section{Youth lack coragem}

The statement 'no one wants to work' is connected to the concept of coragem. Jeremias provides an example: 'whoever doesn't have the coragem to work, really won't work, no matter how much you insist.' Maya Mayblin, also writing about rural Northeast Brazil, explains. ${ }^{43}$

Coragem is an attitude that allows a person to perform work that is, in some way, mentally, emotionally and physically challenging... an embodied state combining both the ability to endure mental tedium and lack of financial reward with the ability to endure physical discomfort and pain... most commonly

\footnotetext{
${ }^{42}$ While I focus on the discourse which portrays unemployed youth as immoral and unmotivated, not all older people express these beliefs. Moreover, many young people are employed and some are enthusiastic about farming. This discourse is, however, a prominent one when discussing work and one which several older adults employed in interviews.

43 Maya Mayblin, 'Learning Courage: Child Labour as Moral Practice in Northeast Brazil'. Ethnos, 75 (2010), p.38.
} 
associated with work in the fields.

Thus, coragem is loosely translated as 'courage' but also refers to strength, endurance and motivation, in both physical and mental senses. Quixadá residents agree that coragem is an essential quality of agricultural workers. I found a widely held belief, as did Mayblin, that children must start working early in order to develop the necessary coragem to be successful even if they do not pursue agricultural livelihoods. Mayblin argues that coragem is part of the moral formation of a person important in the creation of 'hard workers' (trabalhadores). ${ }^{44}$ Those who lack coragem and 'don't want to work' are labelled 'lazy' (preguiçoso) and this has negative moral implications ${ }^{45}$, as evidenced in the conversation between Marcos and Jeremias as well as in Pedro's prediction.

Residents of Quixadá describe several factors that contribute to the apparent lack of coragem among youth. For example, Marcos and Jeremias blame social assistance programs, such as retirement pensions and the umbrella 'Family Allowance' (Bolsa Família) program, for creating a younger generation that is content to be dependent. These social welfare programs implemented by Lula's

\footnotetext{
${ }^{44}$ Ibid, p. 40.

45 The ideals of 'trabalho' and 'coragem' are pervasive in Brazilian agricultural discourse. For example, the moral distinction between the hard-working and the 'lazy' is also discussed by Jeffrey Hoelle, 'Black Hats and Smooth Hands: Elite Status, Environmentalism, and Work among the Ranchers of Acre, Brazil'. Anthropology of Work Review, Vol. 33, No. 2 (2012), pp. 60-72. He cites biblical understandings and developmentalist policies as the basis for the idea that 'work' consists in transforming the land through physical labour.
} 
government were designed to offset some of the negative impacts of neoliberal policies which favour agribusiness and increase the poverty of subsistence farmers. ${ }^{46}$ School attendance is one of the conditions for receiving the Family Allowance, making children unavailable for agricultural work. Furthermore, children under 14 are not legally allowed to work. Thus, failure to develop coragem is explained as the result of state policies and laws which create an opposition between schooling and agricultural labour. The outcome is that many of those who have finished school, or dropped out, are neither studying nor working. They remain dependents of their parents and the state, spending their time in what are considered pointless or immoral activities. Ronaldo, who earlier described the low prices of agricultural products compared to farming inputs, elaborates on how 'the federal government motivates people to commit crimes, to steal, to be lazy, consume alcohol and drugs'. He says that with the Family Allowance, they get $\mathrm{R} \$ 150$ and free food from the supermarket so they don't have to worry about paying for much except for electricity. They can buy clothes and domestic appliances on credit and all they need to do is work a couple of days a month to make enough for the minimum payments. This is what 'deactivates' the farmer, he concludes, and he does not see any 'cure'.

Moral stances emerge as people compare their own choices and

\footnotetext{
46 James Petras and Henry Veltmeyer, 'Whither Lula’s Brazil?
} 
experiences with those of others. When they judge that role expectations (e.g. for worker-citizen) are not being met, explanations are given which contain a moral aspect of laying blame. Following Scheibman, I suggest that generalizations such as 'no one wants to work' or 'young people are lazy' are used to create a division between 'us' and 'them', where the speaker is identified with the morally superior position and the negative characteristics associated with 'them' are highlighted as violations of the social attitudes and cultural beliefs which are ultimately being reinforced through the conversation. ${ }^{47}$ In this case, agricultura is used symbolically to divide moral 'workers' from immoral 'dependents'. Underlying Marcos' and Jeremias' talk is the belief that citizens who work have rights to government assistance, such as pensions or drought relief, because they fulfil their obligation to support themselves and contribute to society. The expected attributes for the 'worker' category, thus, include coragem and autonomy. Relying on family members or state support, dependents incite the moral indignation of people like Marcos and Jeremias because they are believed to be capable but choose to evade their responsibility to work. From this standpoint, the moral failure consists in not striving for autonomy. In taking a moral stance against illegal activities and the state of dependent idleness, older adults align themselves with Christian agrarian

\footnotetext{
47 Joanne Scheibman, 'Subjective and Intersubjective Uses of Generalizations in English Conversations', in Englebretson (ed.), Stancetaking in Discourse, pp. 111-38.
} 
values of honesty, hard work, sacrifice, patience, independence and respect. This is reflected in Jeremias' statement: 'Whoever wants the path of truth, of work, it's a point of honour.' They also take a stance against the state which is seen to have failed in its responsibility to promote autonomy by enabling dependence through social assistance policies. Thus, in describing the actions of other members of the SRP - whether the state or other kinds of citizens - certain expectations about appropriate behaviour and responsibilities are implied, allowing speakers to simultaneously invoke a moral version of themselves. ${ }^{48}$ This bolsters their position both rhetorically and morally.

Whether attributed to a character flaw or to state-sponsored dependency, laziness is not the only reason young people refuse to pursue farming. For example, Angela Steward also reports that younger people in a Brazilian Amazonian community are not interested in farming ${ }^{49}$ She quotes the complaint of a retired farmer: 'Today the youth doesn't want to work. To them, carrying manioc on their bicycles is an embarrassment. They believe that because they are educated, they do not belong in the field ${ }^{50}$ Similarly, a farmer in Quixadá describes how the farmers who occupy settlements created by the state through land redistribution invoke pity rather than admiration.

48 Petraki et al., "'Moral Versions" of Motherhood' (2007).

49 Steward, 'Nobody Farms Here Anymore'

${ }^{50}$ Ibid, p. 87. 
'The poor old guys are all being marginalised, discriminated. People call them shameless, lazy thieves, all baseless criticisms from society...We see the citizens here struggling, they have their house but where is their living? He lives being punished. If the government gives him credit, he'll never pay it back. He ends up selling his land to survive and feed himself because he can't produce any more. And then society, the authorities are mistreating him and punishing him. It's suffering for that citizen.'

Discourses which frame refusal to work as laziness downplay the low social status and the economic hardships endured by subsistence farmers in Quixadá and emphasise the moral character of individuals.

\section{A lack of commitment}

A second discourse explaining why fewer people are supporting themselves by farming portrays moral citizens as those who want to work but who lack resources. The SRP citizen/state is referenced as speakers point to the state's responsibility to assist citizens in need. This discourse is used in taking both a negative stance toward inadequate government policies and assistance programs, and a positive stance toward agricultura. Most small farmers belong to at least one association or union, such as the local Sindicato dos Trabalhadores Rurais de 
Quixadá (Rural Workers’ Union of Quixadá), the Movimento dos Trabalhadores Sem Terra (Landless Workers’ Movement, MST), or the Federação dos Trabalhadores na Agricultura do Estado do Ceará (Federation of Agrarian Workers of Ceará, FETRAECE), in which this moral discourse is employed to mobilise people and resources to improve conditions for semi-subsistence farmers and wage labourers. In Quixadá, Rafael Mendoza provides an illustrative example.

Rafael Mendoza has been fighting for rural workers' rights for nearly 40 years and he is a regional co-coordinator for FETRAECE. Rafael describes the 2010 season: 'This year in terms of grain, food, rice, corn, beans, it's one hundred per cent lost. There is no harvest.' He insists that 'there have to be specific programs for surviving drought.' He says his role is to encourage others and help them get what they need. 'People ask me, "Ah, Rafael, what are we going to do?" and I say "We're going to demand it from the government. If they don't give it to us, we'll take it."' I ask what they want from government. The answer comes a week later at a meeting in the municipal administration office.

The auditorium is filled over capacity with more than 600 people crowding in, mostly farmers from the surrounding districts. The meeting is to discuss possible actions to mitigate impacts of the 2010 drought on local 
agricultural producers. The main topic is the inadequacy and mismanagement of the crop insurance program (Garantia Safra). With few staff, a short deadline and a slow internet connection, the municipal government was unable to complete registration of 1,600 eligible families. There are questions about what assistance those families will receive, what emergency relief will be available, and whether there will be a state-funded work program. The crop insurance program is criticised for being insufficient (about US\$326 per year in 2010), paid out too late, and inaccessible to livestock producers. Representatives from local, state and federal governments as well as various social organizations, such as the MST and the Rural Workers' Union, give speeches. Rafael speaks passionately, his voice loud and indignant, on behalf of FETRAECE.

We family farmers, rural workers, we're going through a difficult time, which, unfortunately, the majority of the authorities are turning a blind eye to. Last year, we lost more than 60 per cent of our harvest to water (due to flooding). Aside from the harvest, we had hundreds of losses, here in this region, with floods, droughts, animals. There was a movement to make demands and ask the state and federal government (for help) and a blind eye was turned on our demands.... So here we are in the middle of the year, we don't have a grain of food because there was no rain 
and a blind eye is being turned by the municipal prefeituras (local administration) too.... Unfortunately for over 30 years, the union movement has been asking municipal, state and federal governments for a program for living with drought but they've never listened... not during the military dictatorship and not in the democracy. Could it be because drought helps with the elections? Could it be because drought is the easiest vote industry? Could that be it?

The crowd applauds loudly with shouts of affirmation. Rafael continues, 'Our suffering is very great, our life in the fields that we are living today, losing our little herds, lacking necessities, our children crying behind us, asking for food. It's very sad.' He describes the kind of drought relief program that is needed: 'a productive project in our communities, to build our cistern, build our fences, make our produce.' He addresses local politicians, reminding them of their authority to help suffering people survive droughts with appropriate programs. He ends with, 'This government doesn't open their eyes to the calamity. For God's sake, it's a huge lack of commitment to the Brazilian people.'

Building on Rafael's discourse about government's lack of commitment to people, and in alignment with his pro-agricultura stance, the representative of the MST, Tarcisio, speaks with practised oratorical skill. He reports that the MST, 
working for over twenty years in Ceará, has been taking actions in the past two months to get the state government to attend to their demands. In the state capital workers have 'occupied' offices of the Secretaria do Desenvolvimento Agrário (Secretariat of Agrarian Development) as well as the state Legislative Assembly and the Instituto Nacional de Colonização e Reforma Agrária (National Institute for Colonization and Agrarian Reform). The MST wants the governor to declare a state of emergency for Ceará because of the catastrophic loss of grain crops (e.g. 70 per cent loss of corn), as well as access to credit, irrigation and a work program. Tarcisio articulates the MST's usual demands for agrarian reform so that squatters, including many of the meeting's attendees, can have access to land and 'conditions for a dignified life'. He echoes Rafael's statement that social movements like the MST and FETRAECE have been fighting for concrete drought mitigation measures to 'resolve the problem of drought in Ceará' for decades. The 'misery insurance' does not do the job. He says the Northeast's problem is not the drought ( seca) but the fence ( c cerca), which surrounds large holdings of unproductive lands and public water reservoirs, denying access to small farmers. Tarcisio concludes that the problem is not the local government of Quixadá, which, led by the Workers' Party (PT) for 14 of the previous 18 years, tends to be sympathetic to their struggle and delivers their complaints to the state government. It's easy to occupy the Quixadá government office; the problem is 'at 
the top', with the state governor, who 'does not have a commitment to agrarian reform and does not have a commitment to agriculture'. Tarcisio incites the workers to engage in 'a great struggle here in the central region of Ceará', declaring that they need to organise the settlements and camps and to join the MST and FETRAECE. 'Are we going to do it or not, my people?' he asks. There are cheers and affirmations. Addressing 'all the workers' of Quixadá, with its history of organizing resistance among rural labourers, Tarcisio finishes with an exclamation: 'We're being called to fight, that is what will resolve our situation! The organised people!' Loud applause erupts.

\section{Government's responsibility is to support agricultura}

Rafael's and Tarcisio's speeches make explicit the expectations regarding rights and obligations of the categories in the SRP citizen/state, which include government's responsibility to mitigate emergencies and to prevent future disasters through proper planning. Associations and unions often take a stance in favour of this type of capacity-building government support, in opposition to neoliberal principles aiming to limit government intervention. This explains both the state's continued resistance and the need for aggressive tactics employed by social organizations in pursuit of assistance. Alluding to the SRP citizen/state, 
Rafael individualises 'government' and describes the collective as one person who 'turns a blind eye' and does not 'listen' to the suffering and demands of the people. The state's continued failure ('for over 30 years') to honour its 'commitment' to provide resources for citizens to support themselves is evaluated as a moral failure in the stance Rafael displays. Furthermore, repeated refusals to create adequate programs that would prepare people for recurring hazards (i.e. drought) is another moral failure because it ensures that suffering continues. In taking this stance Rafael shows solidarity with the farmers in the audience whom he portrays as moral agents, while opposing himself and the farmers he represents to a morally inferior government.

The moral versions of farmers presented by Rafael and Tarcisio contrast with the 'no one wants to work' discourse. Addressing a large audience of farmers, Rafael describes how 'rural workers' are trying to be productive in keeping with the expectations for the citizen-as-worker category, but they are 'going through a difficult time' due to hazards such as flooding and drought. The gravest problem, shortage of food, is not caused by laziness or lack of coragem but by uncontrollable forces and the absence of assistance. Tarcisio goes further, always referring to farmers in the audience as 'workers', while blaming the state government for denying them proper conditions to work for a 'dignified life' by allowing large landholders to retain unproductive lands and prevent access to 
water resources. Distinguishing these workers from dependents, both Tarcisio and Rafael emphasise that they are not demanding food or money, but 'projects' or 'programs' through which they could earn money doing productive work that would bring future benefits (e.g. building cisterns and fences). These statements respond to the pervasive discourse of laziness, including among farmers like Pedro and Jeremias, and they provide an alternative explanation for the dire situation of rural families. Instead of reproducing a moral discourse that internalises the responsibility for production to 'lazy' individuals, responsibility is externalised to the state which is blamed for inadequate assistance and policies that perpetuate inequality.

Rafael rhetorically asks whether government has not created more effective programs for reducing vulnerability because 'drought helps with the elections' and is 'the easiest vote industry'. The audience's applause and shouts signal their agreement. Indeed, the 'drought industry' is well-known by locals and scholars alike. Nelson and Finan describe it as 'the siphoning off of drought relief resources by local elites. Public work projects were used to improve private landholdings... In effect the local power structure turned drought relief into a profitable business,' while money and jobs were offered to secure votes. ${ }^{51}$ Nelson

\footnotetext{
${ }^{51}$ Donald Nelson and Timothy Finan, 'The Emergence of a Climate Anthropology in Northeast Brazil', Practicing Anthropology, 22: (2000), p. 8.
} 
and Finan observe that corruption has decreased; however, government strategies for dealing with drought 'remain mostly reactive rather than proactive' ${ }^{52}$ It is government's reactive stance against which Rafael and Tarcisio construct their own, using agricultura symbolically to comment on the state's perpetual neglect of the rural poor.

In speaking both to and for farmers, the speeches of union representatives like Rafael and Tarcisio share a similar function with those of rain prophets like Pedro and Roberto: symbolically referring to agricultura to construct a moral version of the farmer identity and the citizen/state relationship. The rain prophets remind farmers of their responsibility and capacity to work for their own benefit while association representatives urge farmers to actively work for political change. As voices of the MST and FETRAECE, Tarcisio and Rafael call on farmers to organise and pressure authorities to fulfil their duty to provide resources. Similarly, Roberto calls for the government to distribute seeds. In both contexts, talking about agricultura in particular ways reinforces expectations for moral identities and promotes certain actions. With no financial resources and no capacity to influence global or national markets, peasant farmers lack any real political opportunities to effect change and must rely solely on methods of persuasion of those in power. These moral discourses form the basis for

52 Ibid. 
mobilizing people to join associations, attend meetings, and participate in protests and other attention-getting actions to make demands on government. Facing a government which is unwilling or unable to make progressive changes, discursive stance-taking in such public performances gives farmers a voice which supports their persistence in agriculture and perseverance in political struggle. The gains may be small and temporary but at least they do not quit the only work they know to become dependents.

\section{Conclusion: The symbolic use of 'agricultura'}

In my exploration of how semi-subsistence farmers express their understanding of, and their role within, processes of market liberalisation, I have illuminated how interpretations and attitudes are articulated in discourses about agricultura. I have shown how talk about agricultura reflects and shapes relational roles, especially those of citizen and state, as well as how individuals relate to their work. In particular, public discourse is an important occasion for the construction of moral identities through the deliberate and explicit display of stances. There is a persuasive intent behind stance-taking in public discourses, which aims to validate particular points of view through the creation of (im)moral versions of the identity categories in the citizen/state SRP.

In these moral versions, the speaker's own identity is characterised 
positively because he conforms to expectations concerning the right actions and attitudes toward work, in contrast to others who are characterised negatively for not fulfilling these expectations. For example, before an audience of reporters, politicians and community members, Pedro admonishes lazy and dependent citizens, while demonstrating his own readiness to plant and work. In a conversation with a friend recorded by a foreign researcher, Jeremias describes the lack of coragem among youth nowadays, while emphasising his own integrity and hard work. At a town hall meeting with hundreds of rural workers and local politicians, Rafael criticises the state's deliberate neglect of subsistence farmers, while highlighting the farmers' (and his own) persistence in the face of adversity. In the three discourses presented here-farmers are moral hard-workers, nonworking citizens are lazy, government is irresponsible - the moral value of agricultural work is reinforced. These moral identities and stances can be used to rationalise participation in semi-subsistence farming, to motivate farmers to continue to strive for autonomy, and to persuade the state (and others) to support the work of these citizens. These positive discourses offer a counterpoint to the marginalization and ridicule farmers face in daily interactions with merchants, bankers and other members of urban society.

Whether rural workers are described as hard-working or lazy, as unfairly treated or spoiled dependents, discourses about agricultura provide evidence of 
the peasantry's struggle for autonomy, even if that autonomy is expressed symbolically rather than in measurable outcomes. ${ }^{53}$ Unlike the 'resilient peasantry' Schneider and Niederle describe in Brazil's South, the poverty is greater and the assets are fewer among Ceará's family farmers. For most in Quixadá, autonomy has not been achieved; they do not have stable livelihoods that can withstand shocks such as prolonged drought. Nonetheless, positive stances toward agricultura, taken publicly, uphold the moral value of work and autonomy. This is important in helping people deal with the difficult and disadvantaged conditions in which they work. The underlying belief is that while farmers may be unable to change socioeconomic conditions to increase the monetary rewards of their work, they can increase their moral worth by working. From this perspective, one of the most valuable assets peasants may have is their morality. Thus, taking a positive stance toward the moral aspects of agricultura is one way to defend such work. By the same token, taking a negative stance toward those who do not participate in agricultura blames individuals for their disadvantaged position. In this view dependence is seen as a choice which has only recently become possible with state-sponsored assistance programs, while the larger structural factors that create inequalities, such as restricted access to

53 For a discussion of the peasantry's struggle for autonomy, see van der Ploeg, 'The Peasantries of the twenty-first century'; Schneider and Niederle, 'Resistance Strategies'. 
land and disadvantageous pricing policies, are neither acknowledged nor addressed. Failure to produce is thus explained as moral weakness, manifest as laziness or lack of coragem, just as success in supporting one's family is attributed to individual hard work and moral strength.

The three discourses analysed here are in continual interaction. The celebration of agrarian values, as represented and promoted by rain prophets at the meeting, by union organisers at political events, and by farmers in discussions with an anthropologist, is a deliberate attempt to counter the negative economic reality of agricultural workers, exemplified by the exchange between Dorval and the farmer selling beans. In these positive discourses, the demise of semisubsistence farming is not inevitable if the state fulfils its moral obligation to improve the economic situation faced by farmers through direct assistance and more favourable policies. As one farmer illustrates: 'Alternatives [to rain fed agriculture] for us to survive? Well, we're in the hands of God and the authorities, you know? That's where things are now. If the authorities of our Brazil look after us, we survive.' Individuals are also expected to make an honest effort to support themselves. Thus, we find two kinds of explanation for the decline of subsistence agriculture in Quixadá. One is moralistic and ascribes agency to individuals, locating the failure internally and expressing it as laziness or a lack of coragem. The other locates the failure externally, holding institutions, social structures and 
economic systems responsible for the welfare of citizens, and assigning a more passive role to individuals. In their public roles, rain prophets and union organisers can mediate between these two broad discourses, identifying moral positions for both individuals and government.

Agricultura is a salient topic in rural communities because it is in flux. Far-reaching economic and policy changes are affecting expectations and evaluations associated with particular identity categories, including worker, dependent, citizen, and state. Agricultura is imbued with symbolic value as it is used to represent changing understandings of the roles of citizens and the state, of the position of farmers in society, and of how individuals relate to their work. This makes agricultura a useful symbol for expressing and managing social tensions around work in a transforming rural economy, much the way Rogers argues that 'peasant' works as a symbol for stances on modernity and the state in France. ${ }^{54}$ Moral discourses express and influence how rural citizens are dealing with these changes and challenging power relations in their daily interactions with the broader community and state agents.

As this study is based on interactions with a particular social group, there are limitations. Nearly all participants were actively involved in semi-subsistence

54 Susan Carol Rogers, 'Good to Think: The "Peasant" in Contemporary France', Anthropological Quarterly, 60: 2 (1987), pp. 56-63. 
farming or had been before retirement. Unsurprisingly, there is a prevalence of discourse strategies employed to justify participation in agricultural activities and to reproduce agrarian values, even as the disadvantages of farm work are fully acknowledged. Many older adults in Quixadá grow grains and vegetables as a survival strategy because they lack other options. It would be enlightening to conduct further research among the young and the unemployed to see how they position themselves in relation to the discourses of laziness, dependence, autonomy, morality, and citizen-state obligations discussed above. If they do not identify as farmers or workers, which identity categories are relevant and meaningful to them? Do they refuse to engage in farming because they see it as exploitative and fruitless or are they waiting for better opportunities? How long do they remain dependents? What do they eventually do to make a living? In answering these questions, attention to the language used to frame motivations, choices and relationships can provide insights into the processes of constructing moral identities, in relation to, or perhaps in opposition to, agricultural work.

In conclusion, I have presented local interpretations of what entrenched structural inequalities and the rise of neoliberalism mean for semi-subsistence farming in one region of Northeast Brazil. As it becomes increasingly difficult to support families with semi-subsistence agriculture, rural workers invoke the symbolic value it holds in the construction of a farming identity. Beyond Quixadá, 
anthropological discourse analysis can be applied more broadly to offer a better understanding of value-making in the rural world, providing insights about how people interpret their circumstances and work for autonomy in small ways. The link between moral discourses and identities is important to explore in comprehending the motivations of the rural poor and their attitudes toward their own lives. 